\title{
IMPROVEMENT OF ORGANIZATIONAL COMMITMENT AND JOB SATISFACTION FOR NON-REGULAR WORKERS
}

\author{
Ho-kil Kang ${ }^{1}$ and Hongki Lee ${ }^{2}$ \\ ${ }^{1}$ Professor, Department of Marketing and Management, \\ Osan University, Osan, South Korea \\ ${ }^{2}$ Professor, Department of Management, \\ Jungwon University, Goesan Gun, South Korea
}

\begin{abstract}
The proportion of non-regular workers among all workers in the labor market is on the rise. In such a situation, social interest in the problems and discriminatory treatment of non-regular workers is increasing, and therefore, there is a lot of discussion on nonregular workers. Specifically, research on the problem of non-regular workers, that is, high turnover rate, low commitment, and low productivity, is actively being conducted.

This study analyzes the factors that can affect the organizational commitment of non-regular workers and analyzes their relationship. The purpose of this study is to suggest ways to improve the organizational commitment of non-regular workers. In addition, it was suggested that in order to motivate non-regular workers and increase productivity, it is necessary to establish a fair policy direction and a fair management system for non-regular workers.
\end{abstract}

Keywords: Consumer cooperative, Servant leadership, job satisfaction, job commitment

Cite this Article: Ho-kil Kang and Hongki Lee. Improvement of Organizational Commitment and Job Satisfaction for Non-Regular Workers. International Journal of Advanced Research in Management (IJARM). 12(1). 2021. pp. 12-17.

https://iaeme.com/Home/issue/IJARM?Volume $=12 \&$ Issue $=8$

\section{INTRODUCTION}

The proportion of non-regular workers among all workers in the labor market continues to increase. With such an increase in the number of non-regular workers, not only the government's efforts to improve the discriminatory treatment of working conditions, but also the labor world, there is a strong demand for improving the treatment of non-regular workers. The problem that arises as the number of non-regular workers increases is that discriminatory treatment occurs between regular and non-regular workers in the process of performing the same work. As described above, the problem of discriminatory treatment between regular and 
non-regular workers can be viewed from four main perspectives. First, it is the issue of wages and working conditions for non-regular workers. The wage level of non-regular workers is 50$70 \%$ of that of regular workers even while working the same, and the level of benefits is very low in the welfare sector such as bonuses and additional benefits. Second, it is the problem of non-application of social insurance for non-regular workers. In general, contract workers less than 80 hours per month and less than 1 month are excluded from employment insurance coverage. In addition, short-time workers, daily workers, and temporary workers are excluded from the health insurance and national pension coverage. In reality, most of the non-regular workers are not receiving such social insurance benefits. Third, it is the problem of discrimination in the form of employment. There are employment instability due to contractual discrimination and discrimination in employment status. Fourth, the anxiety and dissatisfaction of non-regular workers can cause labor insecurity through organization. [1-5]

If these problems are not solved and they are prolonged, it will be difficult to achieve the goals pursued by the organization. This is because productivity does not increase when job satisfaction and commitment are reduced. Recently, as the social interest in non-regular workers and their discriminatory treatment has increased, a lot of discussions have been conducted on non-regular workers. However, it is difficult to find answers to problems related to non-regular workers, such as high turnover rates, low engagement and low productivity of non-regular workers. First of all, most of the discussions on non-regular workers focus on the objective situation or fact-finding of non-regular workers, and employment instability caused by the employment type of non-regular workers in the labor market. [3-7] Therefore, in the process of performing work, concrete discussions about the attitude of the employee and how it will affect the performance of the job are not progressing. In other words, there is a lack of research on how the relationship between an organization and an individual affects the attitude or behavior toward work within the organization. Employment stability and organizational commitment can be important indicators in elucidating the consequences of employment patterns in the relationship between organizations and individuals. [8-10] Therefore, the purpose of this study is to improve the organizational commitment of non-regular workers by analyzing the relationship with factors that can affect the organizational commitment of non-regular workers and presenting improvement measures.

\section{METHOD AND OBJECT OF RESEARCH}

In this study, a literature study was conducted to establish a model of the study and hypothesis of the study. A questionnaire survey was used to establish the research model and hypothesis of the study, and to collect statistical data for empirical analysis.

The four variables of job satisfaction, employment stability, wage level, welfare system, and working conditions of non-regular workers were set as the leading variables of job satisfaction. With job satisfaction as an influencing variable, the organizational commitment of non-regular workers was set as the outcome variable. Statistical processing for empirical analysis was analyzed using the SPSS 10.0 program. The method of analysis was to verify the reliability using Cronbach's Alpha coefficients using SPSS 10.0 and the validity test for exploratory factor analysis, and then to confirm the single-dimensionality of each factor and to verify the confirmation factor and hypothesis for statistical verification. Regression analysis was performed.

In the selection of survey subjects for the empirical study of this study, non-regular workers working at manufacturers and service companies were analyzed. The organizational commitment of non-regular workers was set as an outcome variable. 


\section{RESULT AND ANALYSIS}

The survey for this study was targeted to 200 non-regular workers working in the production of small and medium-sized manufacturers and 200 non-regular workers working in the distribution service industry. The survey method was collected at the site after explaining the purpose of the study to the manager of the company and distributing the questionnaire to nonregular workers. Among the collected questionnaires, questionnaires that were not described and tended to be centralized were discarded and 153 copies deemed valid were used as analysis data.

The demographic characteristics of the respondents were 105 males $(68.6 \%)$ and 48 females (31.4\%). By age, 15 people $(9.8 \%)$ aged 25 or younger, 44 people $(28.8 \%)$ aged 26-30, 56 (36.6\%) aged 31-35, $21(13.7 \%)$ aged 36-40, 17 people (11.1\%) are over 40 years old. By education, there were $28(18.3 \%)$ high school graduates and $125(81.7 \%)$ college graduates (including junior colleges). Among them, 98 (64.1\%) were workers in small and medium-sized manufacturers, and 55 (35.9\%) were workers in the distribution service industry.

Scaling is the process of quantifying observations measured based on past experience using systematic laws and meaningful units of measure. The purpose of scaling is to allocate numbers so that the majority of people with the same attribute or attitude have the same score, and there are Thurstone scale, Likert scale, Guttman scale, and the like, of which Likert scale is the most widely used. Reliability refers to the accuracy of consistently measuring the object to be measured with some degree of stability. Since Cronbach's Alpha is commonly used to determine whether or not to maintain internal consistency in reliability analysis, Cronbach's Alpha was also used in this study to evaluate reliability. Cronbach's Alpha represents the correlation between metrics, or between the observed and true scores, as a value between 0 and 1 , and is usually considered to be reliable if the reliability is greater than 0.5 . In this study, it was determined that Cronbach's Alpha coefficient was more than 0.6 to be reliable. Table 1 is the result of analysis of reliability for side variables and items.

Table 1 Result of analysis of reliability

\begin{tabular}{|c|c|c|c|}
\hline Variables & Items & Alpha & $\begin{array}{l}\text { Cronbach's } \\
\text { Alpha }\end{array}$ \\
\hline \multirow{4}{*}{$\begin{array}{l}\text { Employment } \\
\text { stability }\end{array}$} & The current job is very stable. & 0.8311 & \multirow{4}{*}{0.8516} \\
\hline & You may have to leave your current job. & 0.7635 & \\
\hline & I will be fired. & 0.7622 & \\
\hline & $\begin{array}{c}\text { Always worry about the possibility of being } \\
\text { fired. }\end{array}$ & 0.8810 & \\
\hline \multirow{3}{*}{ Wage level } & \begin{tabular}{|c|} 
Current remuneration level \\
\end{tabular} & 0.7886 & \multirow{3}{*}{0.8277} \\
\hline & Considering current salary and job & 0.7801 & \\
\hline & $\begin{array}{l}\text { Considering current remuneration and } \\
\text { social status }\end{array}$ & 0.7967 & \\
\hline \multirow{3}{*}{ Welfare system } & Welfare level of the current workplace & 0.8043 & \multirow{3}{*}{0.8778} \\
\hline & Use of convenience facilities at work & 0.7804 & \\
\hline & Conditions for life stability & 0.8346 & \\
\hline \multirow{4}{*}{$\begin{array}{l}\text { Working } \\
\text { conditions }\end{array}$} & Fair to all employees. & 0.5955 & \multirow{4}{*}{0.6801} \\
\hline & Treated equally with others & 0.5711 & \\
\hline & $\begin{array}{c}\text { Job performance in the same working } \\
\text { environment }\end{array}$ & 0.6721 & \\
\hline & Compliance with labor laws & 0.6086 & \\
\hline
\end{tabular}


Improvement of Organizational Commitment and Job Satisfaction for Non-Regular Workers

\begin{tabular}{|c|c|c|c|}
\hline \multirow{3}{*}{ Job satisfaction } & Overall satisfaction with the current job & 0.7015 & \multirow{3}{*}{0.7491} \\
\hline & It is good to work at the current job & 0.6933 & \\
\hline & $\begin{array}{l}\text { Maximum ability to display in the current } \\
\text { job }\end{array}$ & 0.5892 & \\
\hline \multirow{4}{*}{$\begin{array}{l}\text { Organizational } \\
\text { commitment }\end{array}$} & Accepting all jobs to continue working & 0.7678 & \multirow{4}{*}{0.7884} \\
\hline & $\begin{array}{l}\text { Encourages you to do your best in your } \\
\text { current workplace }\end{array}$ & 0.7478 & \\
\hline & $\begin{array}{l}\text { Sincerely concerned about the fate of the } \\
\text { current organization }\end{array}$ & 0.6812 & \\
\hline & Currently, the company is the best job & 0.7492 & \\
\hline
\end{tabular}

The results of analyzing the significance of the relationship between the variables used in this study, namely employment stability, wage level, welfare system, and working conditions are shown in Table 2. As shown in Table 2, except that the welfare system and working conditions showed a high correlation, the significance of the relationship with other variables was low. The variables with high correlation with job satisfaction were found in welfare system and working conditions, and the variables with high correlation with organizational commitment were found in job satisfaction.

Table 2 Results of correlation analysis between variables

\begin{tabular}{|c|c|c|c|c|c|c|}
\hline & $\begin{array}{c}\text { Job } \\
\text { security }\end{array}$ & $\begin{array}{l}\text { Wage } \\
\text { level }\end{array}$ & $\begin{array}{l}\text { Welfare } \\
\text { system }\end{array}$ & $\begin{array}{l}\text { Working } \\
\text { conditions }\end{array}$ & $\begin{array}{c}\text { Job } \\
\text { satisfaction }\end{array}$ & $\begin{array}{c}\text { Organizational } \\
\text { commitment }\end{array}$ \\
\hline Job security & 1.0000 & & & & & \\
\hline Wage level & -0.1337 & 1.0000 & & & & \\
\hline Welfare system & 0.1152 & 0.2207 & 1.0000 & & & \\
\hline $\begin{array}{l}\text { Working } \\
\text { conditions }\end{array}$ & -0.0134 & 0.1854 & 0.2681 & 1.0000 & & \\
\hline Job satisfaction & -0.1797 & -0.0317 & 0.4014 & $0.5451 *$ & 1.0000 & \\
\hline $\begin{array}{l}\text { Organizational } \\
\text { commitment }\end{array}$ & -0.1986 & -0.0298 & 0.0715 & 0.1430 & $0.3387 \quad * *$ & 1.0000 \\
\hline
\end{tabular}

$* \mathrm{p}<0.05, * * \mathrm{p}<0.01$

Regression analysis was conducted to investigate the effects of employment stability, wage level, welfare system, and working condition factors used in this study on job satisfaction. The regression analysis result was 0.4280 , and the $F$ value indicating the fit of the model was 14.6534, which was $\mathrm{p}<0.001$. This means that the regression model was statistically appropriate.

To verify how the hypothesis, employment stability, wage level, welfare system, and working condition factors of this study affect job satisfaction, employment stability, wage level, welfare system, and working condition factors were selected as independent variables. Multiple regression analysis was performed by selecting the job satisfaction factor as a dependent variable, and the results of the regression analysis are shown in Table 3. 
Table 3 Verification of influence of each variable on job satisfaction

\begin{tabular}{|l|c|c|cc|c|}
\hline \multicolumn{1}{|c|}{} & B & Beta & $\mathbf{t}$ & $\begin{array}{c}\text { Significance } \\
\text { probability(p) }\end{array}$ \\
\hline (a constant) & 1.7888 & & $4.1183 \quad * * *$ & 0.0001 \\
\hline $\begin{array}{l}\text { Employment } \\
\text { instability }\end{array}$ & -0.1665 & -0.2444 & $-2.7046 \quad * * *$ & 0.0086 \\
\hline Wage level & -0.2116 & -0.2326 & -2.5065 & $* *$ & 0.0146 \\
\hline Welfare system & 0.2882 & 0.3492 & $3.6950 \quad * * *$ & 0.0004 \\
\hline $\begin{array}{l}\text { Working } \\
\text { conditions }\end{array}$ & 0.5791 & 0.4913 & $5.2972 \quad * * *$ & 0.0000 \\
\hline$R^{2}=0.4280, \mathrm{~F}=14.6534, \mathrm{p}=0.0000$ & & & & \\
\hline
\end{tabular}

Dependent variable: job satisfaction

$* \mathrm{P}<0.1, * * \mathrm{p}<0.05, * * * \mathrm{p}<0.001$

As shown in Table 3, the regression analysis result was 0.4280 , and the $\mathrm{F}$ value indicating the fit of the model was 14.6534 , which was statistically significant at the $\mathrm{p}<0.001$ level. This means that the regression model was statistically appropriate.

The variables that have a positive (+) effect on job satisfaction were welfare system and working conditions, all of which were statistically significant as $\mathrm{p}<0.01$. This means that when the welfare system and working conditions are high, job satisfaction is high. In addition, employment instability and wage level were found to have negative (-) effects on job satisfaction. It was statistically significant at the significance level $p<0.01$. It can be said that the more insecurity about employment, the lower the job satisfaction appears. The wage level was analyzed to have a negative effect on job performance. In addition, in order to find out the effect of job satisfaction on organizational commitment, job satisfaction was selected as an independent variable, and organizational commitment was selected as a dependent variable, and a regression analysis was conducted. As a result of regression analysis, the $\mathrm{F}$ value indicating the fit of the model was 9.3306, which was statistically significant at $\mathrm{p}<0.001$ level.

\section{CONCLUSION}

In this study, a method to induce organizational commitment through job satisfaction of nonregular workers was studied. In terms of employment security, the research results show that employment instability has a negative (-) effect on job satisfaction, so the organization needs to make efforts to stabilize employment. Specifically, first, indiscriminate short-term employment should be reduced, and companies should employ regular and direct employment in principle. Second, in order to prevent abuse of short-term work, short-time work, and dispatch work, the target work and the target period must be strictly regulated. Third, it is necessary to specify the judicial effect and sanctions regulations, such as prohibiting a period of time in the labor contract. Fourth, the labor supervision function should be strengthened so that illegal irregular employment can be prevented and the law is practically implemented.

In terms of labor welfare, first, the principle of equal treatment between regular and nonregular workers should be established so that non-regular workers are not treated discriminately against wages and other working conditions. Second, the application of social insurance to nonregular workers should be expanded to the same level as regular workers, and measures to improve the management and operation of social insurance should be prepared so that they can actually receive benefits.

Next, looking at the research results in terms of wage level, it was found that the wage level did not affect job satisfaction. However, if you are satisfied with your level of remuneration, it 
is judged that there is a possibility that job satisfaction is high. Therefore, it is necessary to deviate from the current wage structure and consider calculating wages as a result of the evaluation of the job itself.

Finally, looking at the aspect of working conditions, it was found that equal treatment of regular and non-regular employees in the current workplace, and whether or not they comply with all laws and regulations related to work well, affect job satisfaction.

The results of this study provide an important perspective in the management of non-regular workers. First, the results of the study show that the stability of employment, the level of wages for the job level, the welfare system, and equal working conditions affect job satisfaction. Companies need to actively consider these consequences for non-regular workers. In other words, it is desirable to approach personnel management for non-regular workers in terms of improving long-term competitiveness rather than legal issues. Management must be carried out by introducing a division of duties, introduction of an incentive system, the possibility of converting to regular workers, and a management method that excludes visible discrimination. As the results of the study show, in order to actively motivate non-regular workers and increase their productivity, it is necessary to establish a fair policy direction and management system.

\section{REFERENCES}

[1] Lee, B.-H., Worker Militancy at the Margins: Struggles of Non-regular Workers in South Korea. Journal of Asian Sociology, 2016. 45(1): p. 1-37.

[2] Esteban-Pretel, J. and J. Fujimoto, Non-regular employment over the life-cycle: Worker flow analysis for Japan. Journal of the Japanese and International Economies, 2020. 57: p. 101088.

[3] NamKoong, E.J. and D.S. Ma, The effects of job characteristics and non-regular work on the toothbrushing habit and oral check-up in Korean worker: using data from the 7th Korea National Health and Nutrition Examination Survey (KAHANES, 2016). Journal of Korean Academy of Oral Health, 2019. 43(4): p. 204-209.

[4] Choi, B.R. and J. Im Kim, Convergence Study on the Stress Response and Life Satisfaction of a Workplace Worker-Focused on Regular and Non Regular worker. Medico Legal Update, 2019. 19(1): p. 738-742.

[5] Jung, S. and J. Seong, Non-regular worker labor market trends seen through the supplementary results of the economically active population survey by employment type. e-Labor News 138, 2013.

[6] Kang, S. and J. Ahn, Training Effects on Wage and Employment Security by the Non-Standard Worker Types. Journal of Labour Economics, 2013. 36(1): p. 63-91.

[7] Kim, D., The analysis of the impact of panel attrition on estimation of regular-irregular worker wage gap in the KLIPS. 2010.

[8] Osawa, M., People in irregular modes of employment: are they really not subject to discrimination? Social Science Japan Journal, 2001. 4(2): p. 183-199.

[9] Boyce, A.S., et al., "Temporary worker, permanent loser?" A model of the stigmatization of temporary workers. Journal of Management, 2007. 33(1): p. 5-29.

[10] Lyons, E., The impact of job training on temporary worker performance: Field experimental evidence from insurance sales agents. Journal of economics \& management strategy, 2020. 29(1): p. 122-146. 